\title{
Effect of growth and yield parameters on Indian-mustard genotypes under varying environmental conditions in western Haryana
}

\author{
Yogesh Kumar $^{1 *}$, Raj Singh ${ }^{1}$, Anil Kumar ${ }^{1}$ and A. K. Dhaka ${ }^{2}$ \\ ${ }^{1}$ Department of Agricultural Meteorology College of Agriculture (COA), CCSHAU, Hisar-125004 (Haryana), INDIA. \\ ${ }^{2}$ Department of Agronomy, College of Agriculture (COA), CCSHAU, Hisar-125004 (Haryana), INDIA \\ *Corresponding Author. E-mail: yogeshgujjar62@gmail.com
}

Received: June 12, 2016; Revised received: May 2, 2017; Accepted: September 28, 2017

\begin{abstract}
An experiment was conducted in Rabi season of year 2014-15 at Research Farm,Department of Agril. Meteorology, CCSHAU Hisar, Haryana and field area was adjacent to agrometeorological observatory at $29^{\circ} 10^{\prime} \mathrm{N}$ latitude, $75^{\circ} 46^{\prime} \mathrm{E}$ longitude and altitude of $215.2 \mathrm{~m}$ with Split Plot Design as main plot treatments consisted of three date of sowing viz. $26^{\text {th }}$ October, $5^{\text {th }}$ November, and $15^{\text {th }}$ November and sub-plots consisted of three varieties (Kranti, $\mathrm{RH} 406$ and $\mathrm{RH}$ 0749) with four replication. Various growth and yield parameters such as plant height, LAl, dry matter accumulation, partitioning and yield attributes were higher in $26^{\text {th }}$ October sown crop as compared to $5^{\text {th }}$ and $15^{\text {th }}$ November at all the growth intervals. The crop sown on $26^{\text {th }}$ October $(1870.3 \mathrm{~kg} / \mathrm{ha})$ produced highest seed yield as compared to $5^{\text {th }}(1525.5 \mathrm{~kg} / \mathrm{ha})$ and $15^{\text {th }}$ November $(1099.8 \mathrm{~kg} / \mathrm{ha})$.Among varieties, RH0749 recorded highest seed yield because LAl, biomass accumulates were performed better as compared to RH 406 and Kranti. There was significant interaction between growing environment and varieties with respect to growth and yield parameters. From the above study it was concluded that normal or early sowing of Indian mustard may be practisized for achieving higher seed yield and improved growth and yield attributes in western Haryana conditions.
\end{abstract}

Keywords: Growth intervals, Indian mustard, Sowing dates, Yield and yield attributes

\section{INTRODUCTION}

Indian mustard (Brassica juncea) is the second most important oilseed crop in India after groundnut sharing $27.8 \%$ in the India's oilseed production. The crop occupies an area of approximately 6.90 million hectare with a production of 8.18 million tonnes (Shekhawatet al. 2012).In India, the Haryana state contributes $10.2 \%$ to the total rapeseed-mustard production in the country. Likewise, area under mustard in Haryana has increased from 1.98 lakh ha in 1966-67 to 5.70 lakh ha in 2013-14. A considerable improvement in mustard productivity has also happened during the period with its increase from $405 \mathrm{~kg} / \mathrm{ha}$ in $1966-67$ to $1350 \mathrm{~kg} / \mathrm{ha}$ in 2013-14 (Indiastat, 2014).

Growth and yield of Brassica species largely depends upon change in environment during crop growth this change in environment can occur through many practices including sowing dates and water availability. For getting higher yield, sowing time of crop needs to be adjusted with suitable agroclimatic environment (Saha and Khan, 2008). Pradhan et al. (2014) reported that there was significant interaction between date of sowing and cultivars with respect to seed yield of mustard. It was concluded that normal or early sowing of Pusa Jai Kisan or Pusa Bold cultivar may be practiced for achieving higher seed yield, radiation and water use efficiency in semi arid environment of north and north-western part of India. Indian-mustard is much sensitive to climatic variables; hence, climate change could have significant effect on its production. One month delay in sowing from mid of October resulted in $40.6 \%$ loss in seed yield (Lallu, et al., 2010). Gill and Bains(2008) observed a linear and positive relation between leaf area development and photosynthetically active radiation (PAR) interception, which leads to higher dry matter production. LAI plays an important role for crop growth based on its interception and utilization of PAR for producing dry matter (Kumar et al., 2007) and with the delay in planting date, the higher mean temperature was experienced during flowering which led to accelerate the decrease in LAI and reduction in the flowering period. Neoget al. (2005) revealed that as growing degree days (GDD) increased from 1270 to $1684{ }^{\circ} \mathrm{C}$ day in PusaJaikisan and Varuna, the seed yield also increased and with the further increase in GDD accumulation, there was a decline in seed yield. At the value of $1606{ }^{\circ} \mathrm{C}$ day, the yield was found to be highest. Adak et al. (2011) reported that change in sowing dates led to change in thermal environments of the cultivars with respect to different growth and development stages leading to variation in completion of life cycle. Roy et al. (2005) attributed the reduction 
in seed yields to the relatively higher temperature prevailing during the pod filling stage especially if the crop is sown beyond the sowing window (October $1^{\text {st }}$ to $22^{\text {st }}$ ) in 2004-05.

Planting window and mustard cultivars is the most important element for realizing potential yield of crop. Hence keeping these in view, the study was undertaken to investigate the effect of growing environment on growth and yield parameters of three mustard varieties under western Haryana condition.

\section{MATERIALS AND METHODS}

Climate and weather conditions of experiment location in brief: Experiment was conducted in Rabi season 2014-15 at Research Farm of Department of Agril. Meteorology, CCSHAU Hisar, Haryana, India at $29^{\circ} 10^{\prime} \mathrm{N}$ latitude, $75^{\circ} 46^{\prime} \mathrm{E}$ longitude and altitude of $215.2 \mathrm{~min}$ the tract of semi-arid and sub-tropical monsoonal climate. In winter only 2-3 rainy showers are received due to western disturbances followed by low temperature. The occurrence of frost on certain days is also not an unusual feature here. The average annual rainfall in the tract is around $450 \mathrm{~mm}$, most of which is received during southwest monsoon season.

Soil analysis of the experimental field: The soils of Hisar are derived from Indo-Gangetic alluvium, which are very deep and sandy loam in texture and have some amount of calcium carbonate in the soil profile. Physico-chemical analysis of the soil was done by taking random soil samples from $0-30,30$ 60 and $60-90 \mathrm{~cm}$ soil profile depths before sowing of the experiment field.

\section{Soil chemical analysis}

Mechanical composition of soil: Composite soil samples were analyzed by International Pipette Method of Piper (1966) and the results are presented in table 1.

Chemical composition of soil: The chemical analyses of the soil were carried out with standard methods based on composite soil sample of 0-30 cm depth. The values of Nitrogen, Phosphorus, potassium, organic matter, $\mathrm{pH}$ and electrical conductivity given in table 2 were determined with standard techniques and the above analyses indicated that the soil of experimental site was low in organic carbon and nitrogen, medium in phosphorus and rich in potassium and slightly alkaline in reaction.

Experimental details: The data was taken at Hisar station from experiment which was conducted during Rabi 2014-15using split plot design comprising threedate of sowing $\left(26^{\text {th }}\right.$ October, $5^{\text {th }}$ November and $15^{\text {th }}$ November) as main plots and varieties (Kranti, RH 406 and RH 0749) in sub plots with four replications. The package and practices for Indian mustard cultivation was followed as per the recommendation of CCS Haryana Agricultural University (CCSHAU, Hisar).

Plant height: Plant height was measured at 30 days interval till harvesting on five tagged plants in each plot. The height was measured from the base of the plant to the tip of the main stem of randomly tagged plants and expressed in centimeters $(\mathrm{cm})$ and their mean values were calculated.

Leaf area index: The plant leaves separated from samples taken for dry matter were used for determining leaf area from each plot at 30 days interval after sowing. The green leaf area $\left(\mathrm{cm}^{2}\right)$ was recorded using leaf area meter (LI-3000 Area meter, LI-COR Biosciences, Nebraska, USA). The leaf area measured with the help of leaf area meter was used to compute the leaf area index by the following formula.

LAI $=$ Leaf area $\left(\mathrm{cm}^{2}\right) /$ Land area covered by plant $\left(\mathrm{cm}^{2}\right)$

Dry matter accumulation and partitioning: The five randomly selected plants from destructive sampling were used to record the dry matter production at 30 days interval after sowing. The sampled plants were separated into roots, stems, leaves and reproductive parts (flowers, buds and siliquae) and sun dried. Further, the samples were oven dried at $65^{\circ} \mathrm{C}$ to $70^{\circ} \mathrm{C}$ to a constant weight. The biomass/ dry matter accumulation in different plant parts was the converted to weight per square meter.

Yield and yield attributes

Number of primary and secondary branches at harvest: The numbers of primary and secondary branches per plant were calculated at harvest by average values of five plants uprooted for biomass observation in all the treatments.

Seed yield $\left(\mathrm{kg} \mathrm{ha}^{-1}\right)$ : $\quad$ The crop harvested from net plot was threshed after sun drying, cleaned and weighed. The seed yield obtained was converted to $\mathrm{kg}$ per hectare.

Biological yield $\left(\mathrm{kg} \mathrm{ha}^{-1}\right)$ : Biological yield from net plot was calculated and expressed as $\mathrm{kg}$ per hectare. It was taken as the seed yield and stover yield together.

Harvest index (HI, \%) The harvest index for each plot was calculated by dividing the total grain yield by the total biological yield (seed + stover yield) of the same net plot and multiplied by 100 as given below:

$\mathrm{HI}=($ Grain yield $/$ Biological yield $) \times 100$

Statistical analysis: The data were statistically analyzed using analysis of variance (ANOVA) as applicable to split plot design (Gomez and Gomez, 1984). The significance of the treatment effects was determined using F-test at $5 \%$ significance level.

\section{RESULTS AND DISCUSSION}

Weather: In the present study weekly weather parameters during the Rabi season $2014-15$ ( $43^{\text {th }}$ to $15^{\text {th }}$ standard meteorological weeks - SMW) are presented in the table 3 .

\section{Growth studies:}

Plant height: The plant height recorded at different growth intervals in mustard varieties under different 
dates of sowing are presented in table 4. The plant height reduced significantly at 5\% level of significance with delay in sowing. Among varieties, RH 0749 $(195.8 \mathrm{~cm})$ were tallest and RH $406(190.5 \mathrm{~cm})$ second in plant height then Kranti $(175.5 \mathrm{~cm})$. The interaction between sowing environment and varieties was observed to be significant at all growth intervals.

Leaf area index: LAI of mustard varieties under different dates of sowing were recorded at various growth intervals and are presented in table 5.Leaf area index reached maxima at 90 DAS, the LAI reduced significantly at 5\% level of significance with the delay in sowing irrespective of the varieties, at all growth intervals and recorded maximum in $26^{\text {th }}$ October followed by $5^{\text {th }}$ and $15^{\text {th }}$ November. Among varieties, RH 0749 were highest LAI followed by RH 406 and Kranti. The interaction between sowing environment and varieties found significant in 5\% level of

Table 1. Mechanical composition of soil (per cent fraction).

\begin{tabular}{cccc}
\hline Soil depth (cm) & Sand (\%) & Silt (\%) & Clay (\%) \\
\hline $0-30$ & 57.38 & 26.35 & 16.27 \\
$30-60$ & 56.56 & 26.82 & 16.62 \\
$60-90$ & 56.42 & 26.68 & 16.90 \\
\hline
\end{tabular}

Textural class: Sandy loam

Table 2. Chemical composition of soil $(0-30 \mathrm{~cm})$.

\begin{tabular}{lcl}
\hline Particulars & Values & Methods \\
\hline $\mathrm{pH}(1: 2)$ & 7.9 & Glass Electrode pH Meter (Piper, 1950) \\
$\mathrm{EC}\left(\mathrm{dSm}^{-1}\right.$ at $\left.25^{\circ} \mathrm{C}\right)$ & 0.93 & Conductivity Bridge Meter (Richards, 1954) \\
Organic Carbon $(\%)$ & 0.39 & Walkley, Black's and Wat's Oxidation Method (Piper, 1950) \\
Available $\mathrm{N}\left(\mathrm{kg} \mathrm{ha}^{-1}\right)$ & 193 & Alkaline Permanganate Method (Subbiah and Asija, 1956) \\
Available $\mathrm{P}\left(\mathrm{kg} \mathrm{ha}^{-1}\right)$ & 17 & Oleson et al. 1954 \\
Available K $\left(\mathrm{kg} \mathrm{ha}^{-1}\right)$ & 356 & Flame Photometer Method (Richards, 1954) \\
\hline
\end{tabular}

Table 3. Weekly weather parameters during the crop season $2014-15$ ( $43^{\text {th }}$ to $15^{\text {th }}$ standard meteorological weeks - SMW)

\begin{tabular}{|c|c|c|c|c|c|c|c|c|c|c|c|}
\hline \multicolumn{12}{|c|}{$\begin{array}{l}\text { WEEKLY WEATHER DATA - } 2014-15 \\
\text { CCS HAU, HISAR }\end{array}$} \\
\hline SMW & $\begin{array}{l}\text { Max. } \\
\text { Temp. } \\
\left({ }^{\circ} \mathrm{C}\right)\end{array}$ & $\begin{array}{l}\text { Min. } \\
\text { Temp } \\
\left({ }^{\circ} \mathrm{C}\right)\end{array}$ & $\begin{array}{l}\text { G min } \\
\text { Temp } \\
\left({ }^{\circ} \mathrm{C}\right)\end{array}$ & $\begin{array}{l}\text { AVP } \\
(\mathbf{m m} \text { of } \\
\text { Hg) M }\end{array}$ & $\begin{array}{l}\text { AVP } \\
(\mathrm{mm} \\
\text { of } \mathrm{Hg}) \\
\mathrm{E}\end{array}$ & $\begin{array}{l}\text { RH } \\
(\%) \\
\text { M }\end{array}$ & $\begin{array}{l}\text { RH } \\
(\%) \\
\text { E }\end{array}$ & $\begin{array}{l}\text { AVG } \\
\text { WS } \\
(\mathbf{K m} / \mathbf{h})\end{array}$ & $\begin{array}{l}\text { BSS } \\
\text { (Hrs.) }\end{array}$ & $\begin{array}{l}\text { PAN } \\
\text { Evap. } \\
(\mathrm{mm})\end{array}$ & $\begin{array}{l}\text { Rainfall } \\
(\mathbf{m m})\end{array}$ \\
\hline 43 & 32.4 & 19.0 & - & 16.6 & 16.4 & 85 & 47 & 3.5 & 7.0 & 2.9 & 0.0 \\
\hline 44 & 30.7 & 14.6 & - & 12.7 & 11.1 & 88 & 35 & 3.1 & 6.4 & 2.7 & 1.0 \\
\hline 45 & 29.9 & 14.3 & - & 12.4 & 11.2 & 87 & 36 & 2.9 & 6.7 & 2.8 & 0.0 \\
\hline 46 & 27.1 & 7.7 & - & 7.8 & 7.5 & 79 & 28 & 1.9 & 7.1 & 2.4 & 0.0 \\
\hline 47 & 26.6 & 6.9 & - & 7.9 & 7.4 & 88 & 29 & 1.5 & 7.8 & 2.9 & 0.0 \\
\hline 48 & 28.1 & 9.9 & 0.9 & 9.1 & 9.2 & 81 & 32 & 2.5 & 7.7 & 3.0 & 0.0 \\
\hline 49 & 26.9 & 7.9 & 2.6 & 8.6 & 8.9 & 91 & 35 & 2.2 & 7.8 & 1.9 & 0.0 \\
\hline 50 & 20.5 & 6.8 & 2.9 & 8.3 & 8.7 & 94 & 56 & 3.6 & 5.2 & 1.5 & 9.0 \\
\hline 51 & 13.8 & 5.0 & 1.9 & 7.3 & 9.0 & 100 & 88 & 2.4 & 1.6 & 0.3 & 0.0 \\
\hline 52 & 15.0 & 3.9 & 0.4 & 6.9 & 8.6 & 100 & 71 & 2.7 & 4.0 & 0.5 & 0.0 \\
\hline 1 & 16.9 & 2.4 & -1.9 & 6.1 & 8.1 & 95 & 59 & 2.7 & 4.4 & 1.0 & 0.0 \\
\hline 2 & 18.5 & 3.3 & -0.8 & 6.4 & 8.1 & 96 & 52 & 2.3 & 5.5 & 1.2 & 0.0 \\
\hline 3 & 16.4 & 6.5 & 3.7 & 8.3 & 10.8 & 99 & 84 & 3.4 & 2.3 & 0.5 & 0.0 \\
\hline 4 & 18.3 & 8.8 & 5.3 & 9.4 & 12.1 & 98 & 78 & 5.0 & 2.8 & 1.4 & 2.0 \\
\hline 5 & 21.0 & 8.6 & 6.0 & 9.2 & 12.4 & 98 & 72 & 3.4 & 4.2 & 0.8 & 0.0 \\
\hline 6 & 20.6 & 7.9 & 3.7 & 9.3 & 10.9 & 97 & 65 & 4.7 & 6.0 & 1.9 & 4.1 \\
\hline 7 & 19.5 & 5.5 & 1.0 & 7.5 & 10.5 & 95 & 63 & 3.6 & 6.5 & 1.6 & 1.5 \\
\hline 8 & 21.9 & 8.5 & 4.0 & 9.0 & 12.5 & 92 & 66 & 4.5 & 6.4 & 1.9 & 3.1 \\
\hline 9 & 21.9 & 8.7 & 5.1 & 10.0 & 13.5 & 99 & 70 & 3.7 & 6.1 & 1.7 & 3.8 \\
\hline 10 & 22.5 & 9.0 & - & 10.4 & 13.4 & 96 & 64 & 3.1 & 5.7 & 2.3 & 11.3 \\
\hline 11 & 24.9 & 11.0 & - & 10.9 & 14.5 & 92 & 66 & 6.2 & 7.9 & 2.6 & 13.3 \\
\hline 12 & 28.3 & 12.3 & - & 12.0 & 12.2 & 89 & 42 & 3.6 & 8.8 & 3.2 & 1.1 \\
\hline 13 & 28.0 & 15.7 & - & 13.5 & 14.5 & 86 & 54 & 5.2 & 5.5 & 3.7 & 21.3 \\
\hline 14 & 31.2 & 14.3 & - & 13.9 & 12.7 & 88.1 & 38.1 & 5.0 & 9.1 & 4.4 & 8.5 \\
\hline 15 & 33.3 & 16.4 & - & 13.4 & 12.1 & 72.0 & 31.1 & 5.7 & 9.5 & 6.2 & 0.0 \\
\hline
\end{tabular}


Yogesh Kumar et al. / J. Appl. \& Nat. Sci. 9 (4): 2093 -2100 (2017)
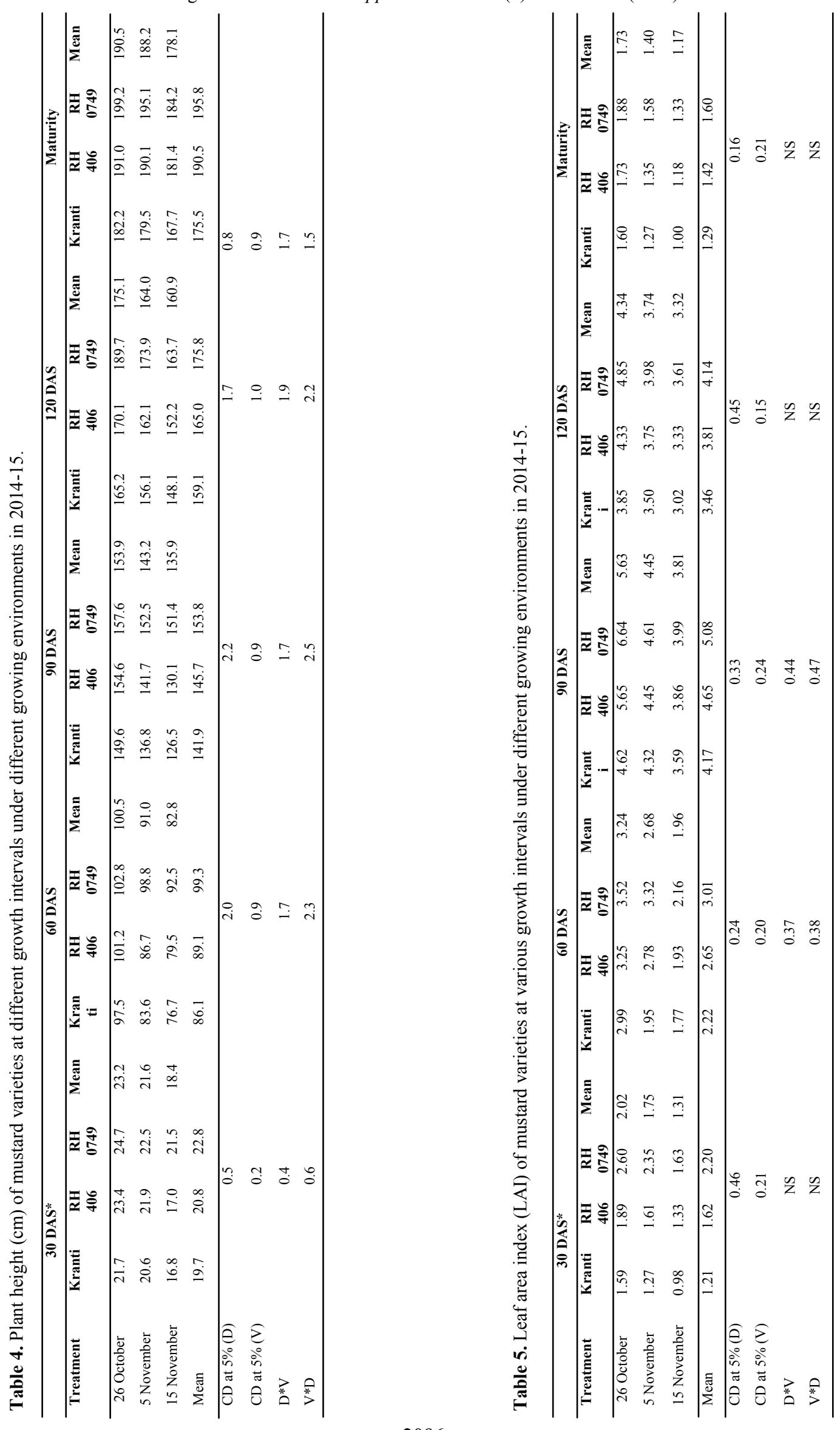





Yogesh Kumar et al. / J. Appl. \& Nat. Sci. 9 (4): 2093 -2100 (2017)

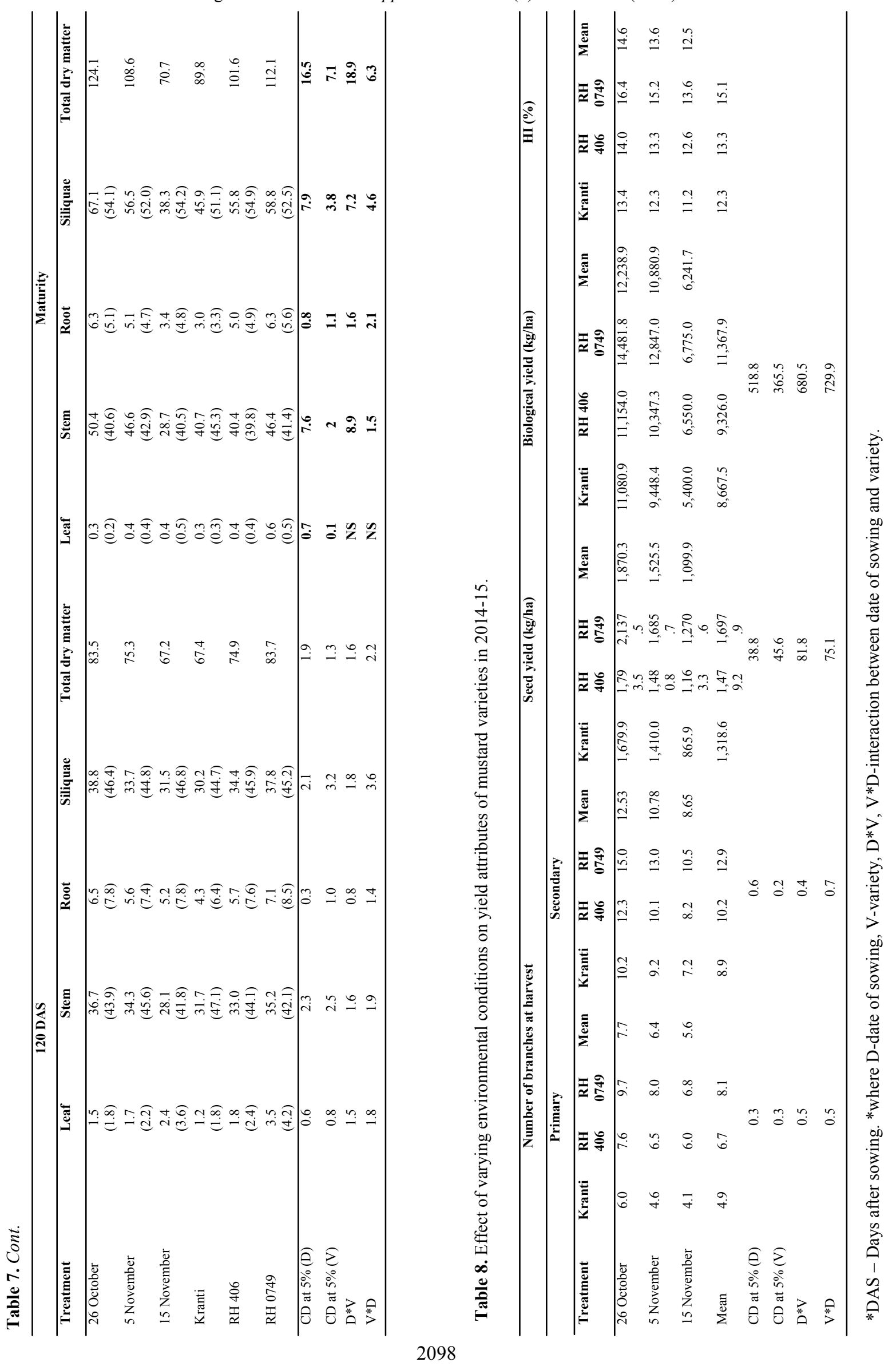


significance at 60 and 90 DAS sowing only. Thereafter with advancement in growth stages up to maturity, interaction effect was observed non-significant.

Dry matter accumulation: The dry matter production by three mustard varieties under various growing environments is given in Table 6. Among the sowing dates, $26^{\text {th }}$ October $\left(124.1 \mathrm{~g} / \mathrm{m}^{2}\right)$ was found to accumulate higher biomass as compared to other dates of sowing. Among the varieties, RH $0749\left(112.2 \mathrm{~g} / \mathrm{m}^{2}\right)$ showed highest value of dry matter per plant followed by RH $406\left(101.6 \mathrm{~g} / \mathrm{m}^{2}\right)$ and $\operatorname{Kranti}\left(89.8 \mathrm{~g} / \mathrm{m}^{2}\right)$ in at all growth intervals. The interaction between varieties and dates of sowing was also found significant except 90 DAS and maturity. RH 0749 accumulate more biomass in $26^{\text {th }}$ October at 30 DAS (6.41), 60 DAS (41.18), 90 DAS (77.85), and 120 DAS (93.15) and maturity $(199.2 \mathrm{~cm})$. These results are in unison with those obtained by Srivastava et al. (2011) in Brassica.

Dry matter partitioning: The dry matter partitioning by three mustard varieties under various growing environments is given in Table 7. During the initial flowering period (30 DAS) the percent allocation of biomass was highest to leaves (\%) followed by stem $(\%)$ and root (\%). At 120 DAS the highest percentage of biomass was allocated to stem. At maturity stage, the highest percent of biomass was allocated to siliqua (reproductive parts of the crop) in all treatment. Higher total dry matter production was produced in $26^{\text {th }}$ October followed by $5^{\text {th }}$ and $15^{\text {th }}$ November. Among varieties, RH 0749 were the higher followed by RH 406 and Kranti. Subsequent delay in sowing recorded significantly lower biomass accumulation in different plant parts at all growth stages.

Yield and its attributes: Effect of varying environmental conditions on yield attributes of mustard varieties in 2014-15 are presented in Table 8.

Number of primary and secondary branches at harvest: The numbers of primary and secondary branches of mustard crop under different sowing environment were recorded at the time of harvesting period. The interaction effect of different sowing environment with varieties revealed that RH 0749 sown on $26^{\text {th }}$ October resulted in highest number of primary (9.7) and secondary (15.0) branches at harvest as compared to RH 406 and Kranti. Among the sowing environment, higher numbers of primary and secondary branches were recorded in $26^{\text {th }}$ October followed by $5^{\text {th }}$ and $15^{\text {th }}$ November at harvesting time.

Seed yield (kg/ha): The result showed that seed yield showed significant difference among sowing dates. The highest seed yield in $26^{\text {th }}$ October sown crop was also due to significantly improved yield attributes as compared to crop sown on other dates. Maximum seed yield was recorded in $26^{\text {th }}$ October $(1870.3 \mathrm{~kg} / \mathrm{ha})$ as compared to $5^{\text {th }}(1525.5 \mathrm{~kg} / \mathrm{ha})$ and $15^{\text {th }}$ November (1099.9 kg/ha). Among varieties, RH 0749 (1697.9) recorded highest seed yield as compared to RH 406
(1479.2) and Kranti (1318.6). These results confirmed the findings Pradhan et al. (2014) in mustard crop at IARI, Delhi.

Biological yield (kg/ha): Among varieties, RH 0749 (11367 kg/ha) was significantly higher biological yield as compared to RH 406 (9326.0) and Kranti (8667.5). Interaction effect also shows that RH 0749 sown on $26^{\text {th }}$ October $(12238.9 \mathrm{~kg} / \mathrm{ha})$ produced significantly highest biological yield as compared $5^{\text {th }}$ November $(10880.9 \mathrm{~kg} / \mathrm{ha})$ and $15^{\text {th }}$ November $(6241.7 \mathrm{~kg} / \mathrm{ha})$. Similar results reported that Kumar et al. (2007) also reported that less amount of above ground biomass yield were recorded from sowing to maturity in Brassica as planting was delayed.

Harvest index (\%): The $26^{\text {th }}$ October (14.6) sown crop recorded highest harvest index as compared to $5^{\text {th }}$ (13.6) and 15 November (12.5) sowing. Among varieties, RH 0749 (15.1) showed significantly higher harvest index as compared to RH 406 (13.3) and Kranti (12.3).

\section{Conclusion}

There was significant interaction between date of sowing and varieties with respect to plant height, LAI, dry matter accumulation, partitioning and yield attributes of mustard. The crop sown on $26^{\text {th }}$ October performed significantly better in respect of growth and yield parameters as compared to mustard sown on $5^{\text {th }}$ and $15^{\text {th }}$ November during the year 2014-15. From the above study, it was concluded that normal or early sowing of RH 0749, RH 406 and Kranti cultivar may be practiced for achieving good yield in the semi arid environment of north-western part of India.

\section{REFERENCES}

Adak, T., Chakravarty, N.V.K., Muthukumar, M., Deshmukh, P.S., Joshi, H.C. and Katiyar, R.K. (2011). Evaluation of biomass and thermal energy utilization efficiency of oilseed Brassica (Brassica juncea) under altered micro-environments. Biomass Bioener., 35: 2254-2267.

Gill, K.K. and Bains, G.S. (2008). Growth-yield dynamics, radiation interception and RUE in Brassica carinata. $J$. Agromet., (Special Issue-Part 1): 72-74.

Gomez, K.A. and Gomez, A.A. (1984). Statistical procedure for agriculture research. John Willey and Sons, New York.

Indiastat, (2014). http://www.indiastat.com/ agriculture /2//152/ areaundercrops 19502014/ 448934/ stats.aspx.

Kumar, G., Adak, T., Chakravarty, N.V.K., Chamola, R., Katiyar, R.K. and Singh, H.B. (2007). Effect of ambient thermal regime on growth and yield of Brassica cultivars. Brassica, 9(1-4): 47-52.

Lallu, R.S., Baghel, V.S. and Srivastava, S.B.L. (2010). Assessment of mustard genotypes for thermo tolerance at seed development stage. Ind. J. Plant Physiol.,15(1): 36-43.

Neog, P., Chakravarty, N.V.K., Srivastava, A.K. Bhagawanti G., Katiyar, R.K. and Singh, H.B. (2005).Thermal time 
and its relationship with seed yield and oil productivity in Brassica cultivars. Internal. J. Brassica., 7(1\&2): 6370.

Oleson S.R., Cole, C.V., Watenable, F.S. and Dean, L.A. (1954). Estimation of available Phosphorus by extraction of sodium bicarbonate. U.S. Dept. Agric. Circ., 939

Piper C.S. (1966). Soil and plant analysis. 368 pp, Hens Publishers, Bombayl.

Piper, C.S. (1950). Soil and plant analysis, (New York: Academic press).

Pradhan, S., Sehgal, V.K., Das, D.K., Jain, A.K., Bandyopadhyay, K.K., Singh, R. and Sharma, P.K. (2014). Effect of weather on seed yield and radiation and water use efficiency of mustard cultivars in a semi arid environment. Agric. Water manage., 139: 43-52.

Richards, L.A. (1954). Diagnosis and improvement of saline and alkaline soils. USDA handbook No.60, United states.
Roy S, Meena R.L., Sharma S.C., Vinod K, Chattopadhyay C, Khan S.A. (2005). Thermal requirement of oilseed Brassica cultivars at different phenological stages under varying environmental conditions. Ind. J. Agric. Sci., 75 (11): 717-721.

Saha, G. and Khan, S.A. (2008). Predicting yield and yield attributes of yellow sarson with agrometeorological parameters. J. Agromet., (Special issue-Part 1): 115119.

Shekhawat, K., Rathore, R.R., Premi, O.P., Kandpal, B.K. and Chauhan, J.S. (2012). Advances in agronomic management of Indian mustard (Brassica juncea L.): an overview. Internal. J. Agron., 1-14.

Srivastava, A.K., Chakravarty, N.V.K. and Adak, T. (2011). Quantification of growth and yield of oilseed Brassica using thermal indices under semi-arid environment. $J$. Agromet., 13(2): 135-140.

Subbiah, B.V. and Asija G.L. (1956). A rapid procedure for estimation of available nitrogen in soils. Curr. Sci., 25: (259-261). 